\title{
A Global Perspective on the COVID 19 Crisis and an Ontological Theology Perspective
}

\author{
Dr Erwin Samuel Henderson \\ Research Fellow, University of Zululand \\ KwaDlangezwa, South Africa \\ Chemin de la Mayre Rousse \\ 26700 Pierrelatte, France \\ erwin@apokatalasso.com \\ DOI: https://doi.org/10.46222/pharosjot.10212
}

\begin{abstract}
This article asks whether human history has any bearing on understanding and interpreting the Covid 19 pandemic. It seeks to examine the historical and present circumstance to identify possible causes, dangers, responses and solutions. It more importantly seeks to respond to the question, is there a possible conjuncture with an ontological theology view of God and the world? The aim of the first section is to present a succinct overview of pandemic themes and in the second, to articulate three significant responses from the ontological theology perspective. This view has for primary focus the reality of the Person of God with emphasis on being and existence, both His and ours in general and specifically in times of crisis. Where is God? Why is this happening? What is He saying? Why does He not intervene? Crises evoke fundamental belief questions. The article therefore, seeks to demonstrate the validity of a cohesive connection between the divine, transcendent and eternal with humanity and human history.
\end{abstract}

Keywords: Covid 19, ontology, theology, existence, God.

\section{Methodology}

Knowledge souces were gathered qualitatively from academics, specialists in their fields addressing the Covid-19 pandemic: science, sociology, economy, history and theology. The validity of this broad context is to: define fundamental and global issues identified through the agency of the crisis and thereby establish a narrative, and to formulate a theological response based on historical and ontological truths. The articles analysed provided authoritative insight into pertinent concepts and thematics that establish historical patterns, necessary to articulate the principal narrative views. The knowledge base utilised is inexhaustive and evolving, but is specific to the divine metanarrative perspective.

\section{Introduction - Covid Overview Contextualized}

While we may be identified as the 'Covid generation', it is historically accurate to insist that in every generation there have been crises typifying the period and the people. Historical events such as: world wars, decolonialisation, the financial crisis, and the refugee displacement evidence the regional or global reality. ${ }^{1}$ With this backdrop, it is helpful to consider the following brief overview of epidemic-pandemics in the Common Era (CE) in order to substantiate their historicity. Antiquity witnesses to annals recording some of the earliest known plagues. ${ }^{2}$ During the Antonine Plague possibly twenty five percent of the world population died due to small pox from the Hun invasion of Germany, and through the military movement, spread throughout the

\footnotetext{
${ }^{1}$ Other significant events are: Post-war reconstructionism, the Cold War, the fall of the Berlin Wall, Apartheid, HIV, and Ebola.

2 The Antonine plague (165 CE), the Cyprian plague (250 CE), and the Justinian plague (541 CE).
} 
Roman empire. In the Middle Ages, of the three major plagues recorded, ${ }^{3}$ disease typically spread through trade caravans from Asia westward. The mortality rate was estimated at thirty percent of the world population (Costantinos, 2020: 564). Similar patterns appear in the Great Plague (1720 CE) in the eighteenth century. In the Provence region of Southern France between twenty five to fifty percent of the population died. During a period of about one hundred and fifty years, (1817-1971 CE), in the nineteenth and early twentieth centuries, seven cholera pandemics were recorded 4 (Waldman and Claeson, 2019; CBC/Radio Canada, 2010). Accumulative death tolls reached from hundreds of thousands to millions. Cholera is distinct from influenza in that it is principally caused by bacteria in unclean water and ingested by humans. The disease spread transcontinentally through people movements along trade routes (Costantinos, 2020: 562-568, 579). Cholera outbreaks have remained significant in the African continent (Waldman and Claeson, 2019). ${ }^{5}$

Influenza is a virus (serotype A H1-16) whose symptoms span from a common cold to severe respiratory infection, which is deadly when complicated by bacterial or viral pneumonia (Smil, ${ }^{6}$ 2020). He suggests that this highly pathogenic H5N1 type originates through crosscontamination with birds or poultry. History witnesses to five major influenza epidemics. ${ }^{7}$ The Spanish Flu (influenza H1N1) has been considered one of the most virulent in human history, "... caused by an unusually deadly strain of 'avian influenza' " (Costantinos, 2020: 562), which spread from a military base in Kansas USA, to Europe, then to North Africa, Japan, and East China in a period of only six months. ${ }^{8}$

This epidemic-pandemic portrait sets the context for understanding the Covid-19 virus group. In a world population of 7.8 billion, there are, at the time of writing, 72.7 million cases of Covid, 1.6 million deaths, 20 million active cases, and 51 million cases of recovery (worldometers, 2020). The primary global impact, observed comparatively, is less reflected in health or mortality rates than in factors of economic and social well-being.

This affirms that bacterial and the more deadly viral influenza infections are recurrent historical features. In comprehending Covid-19, consideration of historical incidence is vital to uncovering the repeated causes, the behaviour of the viruses and effective responses. Prior

\footnotetext{
${ }^{3}$ Black Death (1350 CE), the Columbian Exchange (1492 CE), and the Great Plague of London (1665 CE).

${ }^{4}$ https://www.britannica.com/science/cholera/Cholera-through-history\#ref253250 (Retrieved 18 January 2021); CBC News. (2008) "Cholera's Seven Pandemics" CBC News. 22 October 2010. Available at: https://www.cbc.ca/news/technology/cholera-s-seven-pandemics-1.758504 (Retrieved 18th January 2021). $1^{\text {st }}$ 1817-1821: beginning in Jessore, India spread through Burma, Ceylon, Thailand, Indonesia, Philippines, Iraq, Turkey to the threshold of Europe; along the Arabian trade routes to East Africa and the Mediterranean coast. $2^{\text {nd }}$ 1829-1850: from India to Russia to Finland, Poland, along the trade routes to Hamburg, Germany to Sunderland, UK; on to Quebec and the major East Coast cities of USA, reaching to Mexico and Cuba, with a later resurgence in the UK.

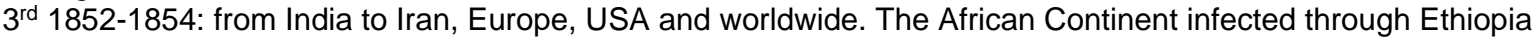
and Uganda. Contaminated water was identified as the source by John Snow.

$4^{\text {th }}$ 1863-1866: from Bengal through Muslim pilgrim caravans to Mecca spreading the disease throughout the Middle East, to Europe, Africa and North America and in Russia.

$5^{\text {th }}$ 1881-1900: from Bengal through Asia, China and Japan severely affected, Italy and Spain and parts of France and Germany latterly to Africa, South America.

$6^{\text {th }}$ 1899-1923 from India quite lethally, through Arabia to the North Africa coast, to Egypt, Russia also sorely affected; while western Europe is untouched, Italy, Greece, Turkey and the Balkans were severely affected. The bacteria receded in India.

$7^{\text {th }}$ 1961-1971 from Celebes, Indonesia affecting Asia, the Middle east and North Africa during a decade.

${ }^{5}$ Cholera outbreaks have remained significant in the African continent: during the Rwanda genocide period (1994), and South America (1991), beginning in Peru, spreading to Ecuador, Colombia, Brazil, and Chile. (Waldman, R, and Claeson, M. (2019) “Cholera”; CBC News. (2008) “Cholera's Seven Pandemics")

${ }^{6}$ Smil, Vaclav: Renowned scientist and best-selling author, Distinguished Professor Emeritus at the University of Manitoba, one of the top 100 Global Thinkers.

7 The five influenza outbreaks are: Russian (1830-1833; 1836-1837; 1889-1890), Spanish (1918), Asian (1957). (Costantinos, 2020: 562-568, 579).

8 The Spanish flu, during the period 1918-1920, recorded 500 Million infections, with an estimated 50 million deaths. Costantinos estimates 100 Million deaths (2020: 562).
} 
to the seventeenth century, epidemics were a one in a hundred year event; in the seventeenth to eighteenth centuries the frequency was once every fifty to sixty years; from the nineteenth century onwards that has increased to once every ten to forty years. In parallel, world population figures for the same periods are estimated respectively at: pre- seventeenth century: 603 million, the seventeenth to eighteenth centuries: 990-1650 million, the nineteenth to twentieth centuries: 1650-6220 million, and in twenty-twenty: 7800 million (ourworldindata, 2020).

Smil (2020) estimates, if the probable source of the Covid-19 virus is poultry to human transmutation, as current poultry growth is estimated at eight-fold, more than double the growth rate of the human population. If so, anticipation of a significant increase of viral recurrence due to the sustained viral reservoir, is probable. His article (Smil, 2020) concisely summarizes the diagnosis that "... eliminating the risk is impossible but making adequate provisions for the next pandemic is not ..."

\section{Eight Global Observations}

The following observations reflect the critical issues emerging from the historical perspective, as outlined in the previous section, that are identifiable or synonymous with the current pandemic.

\section{1) A recurring historical process}

This pandemic represents a repeated historical and generational invitation to change the metanarrative to impact the cyclical crisis principle. Costantinos (2020: 579) writes that "civilisational breakdown is a recurring historical process ... all of our systems - social, political and economic - are being put through what we may regard as a stress test. We will discover which are resilient and robust, which are fragile and brittle ..."

Likewise, journalist Guy Oliver (2020) of The New Humanitarian in South Africa perceives "the pandemic as the watershed moment for the transition ..." The United Nations paper (United Nations Sustainable Development Group, 2020: 22-23) also recognizes the narrative tipping point: "it is clear the world needs a quantum shift in the approach and architecture in pandemic preparedness ... the COVID-19 pandemic can mark the rebirthing of society as we know it today..."

\section{2) Viral transit}

Viral transit was historically and globally vehiculed principally by movement of people or of goods. Smil (2020) warns that global movements of people, animal, and goods simply perpetuates the occurrence of pandemics. The present pandemic substantiates the recurring source of propagation as the context and culture of globalisation. In this, there is no difference from past history, only an intensification of the same problem. These are an unavoidable evil if the globalisation world view remains unchanged.

Therein lies an unresolved tension of global proportions that has profound bearing on the social, economic, cultural and political construct. The palpable friction is whether the nature of current globalisation could or should be significantly remodelled in response to this pandemic mechanism or whether humanity should 'live with it' and get on with life, thereby maintaining the status-quo and living consciously with and accepting responsibility for the risks.

\section{3) Basic health care}

Historical precedence of epidemic bacterial infections establishes a direct correlation with basic health care and sanitation: clean water, food and hygiene. To these infections are added, the variants of influenza viruses that result from cross-contamination and transmutation through the poultry - bird - animal - human chain of infection, as the Spanish pandemic illustrated (Smil, 2020; Costantinos, 2020: 562, 566). Smil (2020) confirms in his assessment 
that "modern hygiene, nationwide and worldwide inoculation, monitoring of infectious outbreaks and emergency vaccinations have either completely eliminated or drastically reduced a number of previously lethal ... epidemic diseases."

Sekyere et al. (2020: 5) report, "the onset of COVID-19 in South Africa has brought to the fore systemic weaknesses in the quality-of-service delivery such as water and sanitation services, housing, healthcare, and infrastructure in various communities across the country."

Some countries, such as South Africa or other African nations including Nigeria, ${ }^{9}$ Chad and the Democratic Republic of Congo ${ }^{10}$ for example, may face compounded difficulties, among other issues. The pandemic has unilaterally shown similar weaknesses globally, irrespective of economic or political policies. This issue points to the tension of human versus socioeconomic factors.

\section{4) Global Methodology}

In relation particularly to Africa, Ozili identifies nine common Covid-19 prevention policies (2020: 21):

1) school closing (SC)

2) workplace closing (WPC)

3) cancel public events (CPE)

4) restrictions on gathering $(\mathrm{ROG})$

5) close public transport (CPT)

6) stay at home requirement (SHR)

7) restrictions on internal movement (RIM)

8) international travel controls (ITC)

9) income support (IS)

Symptomatic of globalisation when faced with such a pandemic, it is fair to say most countries have applied the same emergency measures to some degree. The variant lies in the degree of cultural appropriation of these measures in compliant conformism or anti-conformism. For example, Verdier-Molinié, (2020), writing in the Nouvel Observateur comments that France is said to hold first place in Europe for the application of unilateral restrictive measures, described as the "unrivalled ultra-centralisation of authority" which have resulted in a wave of antiliberticide protestations. By comparison, other European countries such as Italy, Germany, and the United Kingdom are cited for their principles of democratic consultation and decisionmaking process. ${ }^{11}$ The legitimate aim of such protestation targets consultative, inclusive democratic processes as distinct from populist anti-liberticide protestations throughout Europe. In Europe generally, there is a crisis of individual liberties and a cruel absence of collective

\footnotetext{
${ }^{9}$ Seventy percent of Nigeria's population does not have access to clean water and sanitation.

Rodriguez, Leah (2019) 4 Factors Driving the Water and Sanitation Crisis In Africa. Global Citizen, Johannesburg, 7 October 2019. Available at: https://www.globalcitizen.org/en/content/water-and-sanitation-crisis-sub-saharanafrica/ (Retrieved 13 March 2021).

10 Fifty percent of the population in the countries cited does not have access to clean water. Access to sanitation ranges from seventy five percent in Equatorial Guinea to eleven or twelve percent in Niger, Togo and Chad. United Nations Sustainable Development Goals. (2015) UNICEF Urges Swift Action, 'Robust Financing' to Close Water and Sanitation Gaps in Sub-Saharan Africa. UNSDG, 16 December 2015. Available at: https://www.un.org/sustainabledevelopment/blog/2015/12/unicef-urges-swift-action-robust-financing-to-closewater-and-sanitation-gaps-in-sub-saharan-africa/ (Retrieved 13 March 2021).

${ }_{11}$ Molinié-Verdier, Agnès. (2020) TRIBUNE : «Urgence sanitaire et libertés publiques : la France, cancre de l'Europe ? " (Health Emergency and Public Liberties: France, Dunce of Europe?) Le Nouvel Observateur, Paris, 5 November 2020. Available at: https://www.nouvelobs.com/politique/20201105.OBS35703/tribune-urgencesanitaire-et-libertes-publiques-la-france-cancre-de-l-europe.html. (Retrieved 13 January 2021).
}

Agnès Molinié-Verdier, Director of the Foundation for Research on Administrations and Public Politics (IFRAP). 
responsibility. The South African concept of 'ubuntu' captures the spirit of the individual connected integrally to the collective community - an advantage in cultural DNA to be preciously guarded and reinforced, and an example to the individualistic driven West.

What is clear is that these emergency measures are imperatively temporary in the light of the difficulty of maintaining social, economic and political cohesion. The need for such measures and their temporality creates a space for the underlying emergence of a new normal.

\section{5) "Human capital" and Relational Fracture}

Ozili (2020: 26) coins the significant term, "human capital," encompassing measures that restore the significance and primacy of the human factor in order to better the social and economic considerations. He clearly advocates a necessary reordering which should logically be applicable globally: if human well-being and health are in their proper place then social cohesion and economy will recover. He continues to emphasize that "... social policies matter to all individuals regardless of socio-economic position since it is positively linked to overall population health" (2020: 3-4). As lockdown-containment regulations apply, "social separation ... can hurt social cohesion ..." (2020: 8-9) compounded by those carrying the stigma of having contracted Covid-19. The loss of "... social activities that promote social development because large parts of the African society depend on person-to-person interactions," is one cause of relational breakdown in African society (Ozili, 2020: 17). While this problem may be particular to African and Oriental contexts, it is symptomatic globally.

In this light, the emphasis is upon the vital human and relational hub that takes primacy over structure and economy. Confined 'intra-family' relationships have revealed high levels of breakdown, of increased domestic violence: Sekyere et al. (2020: 3) report of "... social aggravations and conflict among people stuck together during the lockdown, especially in dysfunctional homes and incohesive or crime-ridden communities." The impact of this human 'mal-être' renders the relational-community structure more vulnerable, affecting profoundly our society, human behaviour, our well-being and mental health (UN SDSN, 2020).

The statistical swing is observed: from a decrease in 'extra-family' crime and violence, due to restrictions upon free movement, to an increase in 'intra-family' dysfunction. There appears to be nothing more than a transferal of the problem rather than a sign of betterment in human behaviour. When economic priorities reign, the result is in the dehumanising of human quality and relationality. It corroborates that to be socially secure or economically stable or affluent does not improve human quality, which the crisis has shown.

\section{6) Societal Trust Crisis}

The pandemic has compounded an already disintegrating phenomenon: the crisis of societal trust between governments and their policies and compliant citizens. Bennett (2020) comments, "we want the public to trust experts, but only where they have good reason to do so ... (public trust) is both a necessary and desirable feature of an effective public health response to the pandemic. But it is desirable only insofar as it is well placed trust". ${ }^{12}$

Similarly, in a South African context, Devermont (2020), of the Center for Strategic and International Studies, calls the government to "... focus on increasing transparency and accountability ... By making (this) information accessible to the public, the government will garner the trust of civil society, helping to reduce ... corruption and misallocation of donated funds."

This crisis of societal trust is a global issue; in Europe, accusations of totalitarian policy and liberticide regulation suggest the underlying issue of trust is more significantly barometric of

\footnotetext{
12 Matthew Bennett, Cambridge University lecturer in Philosophy and Leverhulme postdoctoral researcher at the University of Essex.
} 
societal cooperation. The United Nations recognizes the pandemic as "... a crisis of confidence ..." (United Nations SDG, 2020: 20). It reiterates the global call "... for leadership, solidarity, transparency, trust and cooperation." (UN SDG, 2020:11).

By way of response, Bennett suggests two strategies: firstly, "multiple meanings" in order to appeal to the divergent majority to induce consensus in the appraisal of the situation and the implementation of policy. Simply said, this is to present a proposal in such a way that opposing parties find something they can identify with and adhere to. Secondly, is that of "identity vouching" whereby personality-influencers as trust-inducing figures create an atmosphere of general acceptation and trust. These could be seen to reflect a politicized disingenuity; the compatibility with public expectation of genuineness and transparency remains to be seen. According to the United Nations, "this is no time for self-interest, recrimination, censorship, obfuscation or politicization" (UN SDG, 2020: 11).

In summary, the societal need for a clear demonstration of transparency, accountability, solidarity and cooperation defines the nature of the trust that is implicitly and explicitly called for. Realism necessitates that the unrealistic societal demands for miracle-workers be abandoned and that it is the nature of: the relationship, the communication, and the practical implementation that will nurture cohesive trust.

Trust is an ontological concept; it is placed in a person, rather than in a thing or for something. Someone who is able to demonstrate what they have done, what they have said, and reflect who they are, defines trustworthiness. In other words, trustworthiness tangibly demonstrated engenders genuine trust, attested by the divine archetype; the historical person of Jesus-Christ is proof of the trustworthiness of the person of God. ${ }^{13}$ In essence, this is the integrity of trust. ${ }^{14}$

\section{7) Religious Factor Influence}

In contrast to the major European nations where secularisation has side-lined any religious significance to the sphere of personal rather than public life, South Africa and other continent nations have a public and integrated relationship to the religious factor influence. In most of sub-Saharan Africa, "religious leaders are perceived as more credible and trustworthy than other leaders ..." (Devermont, 2020). This heightens the opportunity and the responsibility for a coherent religious or theological understanding and contribution to national and international recovery.

Herein lies a legitimate opportunity for religious scholars and Christians, as a majority representation in South Africa, to communicate the credibility and genuineness of the Christian-Biblical interpretation of world events, of God as He relates, operates and communicates, and of a heightened sense of purpose. In this, the cacophony of populist voices, from apocalypticism, conspiracism, to rational anxiety minimalism, only obstruct and obscure a biblically founded overview in the redemptive historicity of God. The supposition is that if the pandemic is a recurrent pattern throughout history, with its reasons and lessons to be learned, likewise, if God is implicated in human history, then there are also ramifications from divine reasons and lessons.

\section{8) Genericity of Globalisation}

Genericity ${ }^{15}$ as a primary characteristic of globalisation is an attempted form of rewriting the human metanarrative. Genericity, in opposition to uniquity, ${ }^{16}$ is one historical key to empire building, where by choice or policy, local and regional culture, contextual understanding,

\footnotetext{
13 John.3:16; 14:8-9; Romans 3:25-26; Ephesians 1:18-19; Hebrew 6:17; Psalm 19...

14 Isaiah 45:23; 46:10; 55:10; Ezra 1:1-2; Luke 4:17-21; Romans 5:8.

15 Oxford English Dictionary, "Genericity" The property of being generic, especially in some technical sense of the word. https://www.lexico.com/definition/genericity. Retrieved $17^{\text {th }}$ February 2021.

16 Oxford, "Uniquity" The quality of being unique, uniqueness. https://www.lexico.com/definition/uniquity. Retrieved $17^{\text {th }}$ February 2021.
} 
perspectives and methods have been undermined, invalidated, and considered antiquated. The expression of uniquity has been engulfed by the generic with its promise of betterment.

Costantinos (2020: 556) refers to "... the process of the retrieval of community history, and adaptive strategies within that framework that is robust and historically sedimented in the national heritage" as an important part in addressing the pandemic and implementing solutions. This assertion validates the significance of community uniquity over global genericity as part of the solution. If deglobalisation and de-regionalisation were to accelerate, how would this movement's relationship to globalisation be formulated: is this recovery of uniquity simply a positive benefit of globalisation or as a result of its fragility?

Kharas and McArthur (2020) observe similar apprehensions, “... despite the inherent need for global cooperation to defeat a pandemic, Covid-19 seems to have reinforced nationalism rather than internationalism ..." They use the budgetary chasm of investment between advanced and other economies in response to Covid-19 to substantiate their claim: an estimated budget of eleven trillion dollars on domestic responses while the appeal for a thirtyfive-billion-dollar contribution to the global response has failed.

The inter-disciplinary and trans-national work of the medical sciences has demonstrated the benefit of global networking and collaboration, global reactivity and solidarity (Costantinos, 2020: 579). However, the complexities of this reality are illustrated in the simplest of examples taken from the manufacture of a pair of 'ecological' denim jeans: the cotton is harvested and spun in India, sent to Thailand for weaving, then expedited to Germany for dyeing and transported to China for assemblage for global market distribution. ${ }^{17}$ This underlines the ecological conundrum of global economics and exemplifies the fragility of supply chains perilously dependent on global functionality and efficiency. Beyond the economic and ecological considerations, these examples underline the dilemma raised by the generic global relationship to the uniquity and alterity of human identity, culture, and expertise.

In this regard, Costantinos rightly identifies a cyclical pattern,

Civilizational breakdown is a recurring historical process ... complexity means higher levels of heterogeneity .... as social, economic, and political orders become more complex they also become more fragile and brittle, less resilient and adaptable. They become less able to cope with unexpected shocks ... A major pandemic is one of the classic aspects of a civilizational crisis. (2020: 579-580)

He goes on to describe a counteractive dynamic as,

the innovative process (which) can be spurred by the challenge of reaching a natural limit, opening up ways of pushing that limit further out and so checking or reversing the breakdown ... (where) we should be confident that global civilization would overcome this, as it has before. (2020: 580)

Two issues should be noted: firstly, rather than fear deglobalisation in favour of the national or regional culture, this historical turning point where the genericity of globalisation is not coping or is at breaking point, represents a hope filled opportunity for a new framework, and for a new expression of internationalism that reflects the space given to indigenous and cultural alterity. Secondly, this assertion "to push beyond the natural limits" may risk facilitating the cyclical pattern rather than diminishing or solving it, thus doing no more than causing entry into another historical cycle of the same, where no lessons have been learned and change is inhibited.

\footnotetext{
17 Global Economy Documentary: Ecological Denim Jeans. (Television Programme), France Télévision, France, 14-17H, (date unknown), December 2020, France Info, 15mins.
} 


\section{Summary}

To conclude, there are several indicators that significant change is on the international agenda, which might go some way towards Ozili's (2020: 26) social reordering or to the globalisation crisis whose paradigms facilitate pandemics, and whose genericity confronts the legitimacy of cultural alterity seeking authentication and restoration. The effects of the virus touch every sphere and strata of human community and productivity. In terms of paradigm shift, the United Nations scientific advisors and associated networks identify concurrently six 'entry points' or 'transformations' (UN SDSN, 2020):

1) Human well-being (poverty, health, education, gender equality)

2) Sustainable economies/industries

3) Accessible and Sustainable food and nutrition, water

4) Decarbonized energy

5) Sustainable urban city development

6) Sustaining the common environment (oceans, climate, biodiversity)

The United Nation's impetus seems to have captured the spirit of Ozili's vision of "the human capital" 18 with a determined focus upon "... people - families, women, children, youth, persons with disabilities and the elderly... meeting peoples most immediate health and ... basic needs ... protecting the household income ..." (UN SDG, 2020: 13-14).

Sustainability, as the second major priority, encompasses the other five points suggesting that the United Nations and the European Union recognize the language of development rather than growth (Ozili's reordering) and of resilience underpinned by a widely endorsed ethos of equity and sustainability.

In this section, the eight observations synthesize the global Covid-19 overview and the associated challenges to life in this generation, providing the contextual backdrop to which ontological theology seeks to bring a perspective encompassing divine truths revealed in God.

\section{Ontological Theology Perspective}

If theology, and in particular the ontological frame of reference, has a contribution to make, then its significance requires the formulation of two assertions upon which the validity relies:

1) God exists and is personal-relational

2) belief that God is intentional and provides a basis for meaning and understanding.

This section focuses on three fundamental areas emergent from the preceding observations. The ontological theology perspective elaborates responses to: globalisation, paradigmmetanarrative challenges, and crisis interpretation. The subsequent argument addresses the basic belief crisis questions: Where is God? Why is this happening? What is He saying? Why does $\mathrm{He}$ not intervene sovereignly? The reactionary movements mentioned under the "religious factor influence" exhibit some of the complexities and pitfalls. These concerns not only affect religious leaders, they also influence wider societal trends, in that they often provide minimal metanarrative grounding. The theological challenge is to provide a coherent pastpresent-future perspective because of the divine metanarrative, which could affirm Christian leaders and communities in their contribution.

\section{Response I: Globalisation}

There is a line of centenarian oak trees in the wood near my home. As the imperceptible roots have grown proportionately to the visible tree, they reached the point of full growth. They continue to produce leaves and acorns year after year but they no longer expand in the same

\footnotetext{
18 Priority towards people, then health, to restore societal cohesion and re-establish the economy.
} 
way..$^{19}$ This observation from nature teaches that continuous expansion is not in the natural order. If that is the case, there comes a point when prosperity, economic, social or otherwise, is not defined as always increasing, but by a quality that reproduces the necessary measure in its season. Constant expansion inhibits this qualitative, sustainable kind of prosperity illustrated, from taking sufficient root to stabilize with any permanency, humanity and community.

\section{Inherent boundaries}

In response to Costantinos (2020: 580 ) who suggests that "the challenge of reaching a natural limit, opening up ways of pushing that limit further out and so checking or reversing the breakdown," the observational lesson advocates that the created order will naturally exist and function within innate boundaries; there is therefore a limit not to be transgressed. Progress cannot always be qualified as pushing the boundaries, rather recognition of them invites a move from a quantitative to a qualitative paradigm.

\section{The Price to pay}

History teaches repeatedly a lesson that we have such difficulty accepting: when entities get too big, they break. The Roman empire, regardless of military, political, economic and structural prowess, broke, as did the Assyrian, Babylonian, Persian, Islamic and Ottoman empires. In recent colonial and empire history (British, French, Spanish and others) all have succumbed to the inevitable expansionist outcome. With this historical and empirical precedent in view, therein lies the danger for the global construct that is difficult to ignore.

As observed, the cyclical nature of epidemics is therefore of no surprise. If we insist on the same model of globalisation. Pandemics such as Covid-19 and future viral strains will only increase and intensify. The crisis is socio-economic in that the mode of living that has been sacrosanct in the West, that politics and economics have sustained, now requires significant transformation and increased conformity to the inherent natural order. The paradigm change concedes the self-elected normalized mode of living for a renewed quality of human existence. If the principle is to be accepted, there has to be some correlation between the extent of the problem and the measure of radicality in the transformational response.

\section{Genericity of Globalisation}

Lebakeng (2020) referred to the principles of homogeneity and alterity ${ }^{20}$ in his paper on the relationship to the indigenization of an African educational vision, delivered at Zululand University Humanities and Social Sciences virtual conference 2020. ${ }^{21}$ Homogeneity and alterity are two significant concepts for the ontological theology perspective.

By nature, the globalisation construct uniforms, standardizes, and as it does so, subjugates and represses uniquity and alterity wherein is found a wealth of particular wisdom and insight. Masoga (2020: 16, 43) of Zululand University has written particularly regarding South Africa,

African heritage resources are seen to be in danger of obliteration by the forces of globalisation, which tends to promote the thought processes and cultural values of the economically dominant western countries ... because the politics of western civilisation have operated

\footnotetext{
19 "Trees do stop growing in height ... the slowing in growth is related to age. After growth stops some species will live on another one hundred years, during which width is added and new branches sprout throughout their lives." EarthSky. (2011) What Makes a Tree Stop Growing? $1^{\text {st }}$ January 2011. Earthsky. Available at: earthsky.org/earth/what-makes-a-tree-stop-growing. (Retrieved $1^{\text {st }}$ March 2021).

20 Oxford, "Alterity" The state of being other or different; otherness. Retrieved 17th February 2021.https://www.lexico.com/definition/alterity.

${ }^{21}$ University of Zululand Humanities and Social Sciences 11 $11^{\text {th }}$ Virtual Conference 2020: "Covid-19: Community, Commitment, Controversy and Challenges" 15 December 2020.
} 
on the basis of mono-knowledge and the suppression of all other knowledge ...

Genericity of globalisation requires clarity as to its limitations. If the value system is refocusing on the human factor, it is a logical self-imposed consequence that uniquity in alterity be fundamentally restored. It is not limited to the demands of education or national identity; it is an existential ontological imperative, a prerequisite to any transcultural ${ }^{22}$ construct.

\section{Homogeneity and Alterity Paradigm: Identity and Space}

The ontological theology perspective anchors homogeneity and alterity in the Person of God and his intentions, which is manifest in concepts of identity and space (territory):

1) 'I Am' personal covenant making God (identity), seated over the heavens and the earth (territory). ${ }^{23}$

2) Adam and Eve are made alive, given names (identity); placing them in a garden (space), where identity and cultural are nourished. ${ }^{24}$

3) God's promise to Abraham: a people (identity); a territory, (space). ${ }^{25}$

4) The apostle Paul's vision of the nations, "... He himself gives to all humanity life and breath and everything (identity). And he made from one man every nation of mankind to live on all the face of the earth, having determined allotted eras and the boundaries of their dwelling place (space), that they should seek God ... and find Him."26

The divine perspective does not challenge concepts of individuality nor identity, they are normative and evident. The homogeneity and alterity paradigm, expressed in identity and space, authenticates the restoration of identity uniquity and community alterity as vital. Based on the transgression of this limit, the nature of 'extra-identity' and 'extra-ethnic' relations and co-operations can only be problematic. Assault upon the identity and space, alterity and uniquity paradigms between ethnic peoples, result in deculturation (loss), acculturation (assimilation), and transculturation (admixture), the same methods used by the empires in antiquity. ${ }^{27}$ Where violations occur, the mandate is to restore the inviolable "identity-space" paradigmatic imperative, which requires compliance to the principles legitimizing and authenticating uniquity and alterity rather than subjugation to genericity and homogeneity.

The globalised expression of Christianity could mistakenly be suspected of being founded upon the latter fundaments, however, the uniquity and alterity of the person of Christ, is Christianity's authentic paradigm. New Testament thought recognizes ethnicity plainly. The person of Christ being revealed in an experiential manner to the nations is the divine intention; ${ }^{28}$ in this, uniquity and alterity are accentuated by what it means to be ontologically Christian in a specific cultural context.

\section{Homogeneity and Alterity Archetype}

The archetype of homogeneity and alterity in substance, in personhood, and in relation is found in the Godhead; the three Persons of the Trinity being perfect ... in the same nature and attributes. ${ }^{29}$ Based upon the divine archetype, "a relational complicity between the individuality of Perfects" (Henderson, 2019: 56-57), this homogeneity in nature serves to establish relational

\footnotetext{
22 Oxford, "Transcultural": relating to or involving more than one culture; cross-cultural. https://www.lexico.com/definition/transcultural. Retrieved $17^{\text {th }}$ February 2021 . Transculturation refers to the relationship and influences between cultures.

23 1Kings.8:27; Isaiah 66:1.

${ }^{24}$ Genesis $1: 27-28 ; 2: 7-9,15,22-23$.

25 Genesis 12:2-3, 7; 15:5-7; 17:1-8.

26 Acts 17:25b-27a.

272 Kings 17:7-8, 24, 29-34; 2 Chronicles 36:17-20.

28 Romans 16:25; Galatians 3:8; Revelation 7:9; 5:9-10; $21: 24$.

29 John 1:1-3 establishes eternal divinity, eternal equality, and eternal relationship-unity, in being and then in operation, the example in this context is creation.
} 
and operational unity. ${ }^{30}$ This archetype implicates the divine intention for humanity, created according to the resemblance of God, ${ }^{31}$ to corroborate this definition and purpose in the human community, even if a pale reflection of that perfection.

Homogeneity is recognized, as one person calls out to another, "bone of my bone (substance), and flesh of my flesh (likeness) ..."32 The 'human factor' therein, finds its true origin and basis for relationality and unity in existential equality. The restoration of social-relational cohesion depends upon the restoration of this thinking to heal humankind's humanity. The ontological Christian finds Jesus-Christ indwelling to reflect the divine nature ${ }^{33}$ as the source of relationality and unity, thereby expressing the ultimate intention of God. ${ }^{34}$

The divine model of alterity operates within the framework of "complicity between Perfects." In Godhead, alterity provides the basis for "... a collaborative relationship between perfect likeness and equality ... without contradiction" (Henderson, 2019: 104). This means specificities in personhood and activity that distinguish the persons of the Godhead emerge reinforced by the quality of relationship hallmarked by unity of being and purpose. ${ }^{35}$

Within the human framework when a person, a particular knowledge, an experience, a perception or an understanding is enjoined alongside another, one alterity is added to another, a greater fullness is expressed: the sum of which is greater than the individual parts. This is called 'perfecting', an imperfect reflection of the perfect divine alterity prototype. Consequently, homogeneity creates the relational basis on which alterity in personhood and activity flourishes. Herein lies a divine archetypal response to relational crisis.

This shaking of the globalisation tree is an invitation to carve out a new route to this kind of relationality in collaboration towards perfecting or completing fullness. Surely, there is in human ethnicity, a conscious or subconscious aspiration to this reality. This goes some way to explaining the inherent existential crisis and need to transform the homogeneity-alterity relationship, from a divine theological perspective. If implemented, the potential is for: affirmed identity, intensified cultural belonging and appropriation, new initiatives engendered through renewed creativity and originality of alterity, opening the way to effect change towards a new relationality paradigm.

\section{Response II: Metanarrative}

In crisis, urgency predominates thinking and action addressing specific circumstances (e.g., Ozili's (2020: 21) nine criteria). Shaping the future reaches beyond these particularities, by shaking the foundations of the human story. The belief crisis questions also call to examine origin and destiny, two realities in view when Jesus says, "... my witness is true, for I know where I came from and where I am going ..." (John 8:14 ESV). The examination of these realities determines the ontological construct.

\section{God: Space and Time}

King Solomon, $3^{\text {rd }}$ king of Israel, wrote, “... eternity He has set in their heart without which man cannot find out the work that God makes from the beginning even to the end" (Ecclesiastes 3:11 $\left.\mathrm{TIB}^{36}\right)$. Solomon correlates a concept of time with existence; of eternity (continuous time

\footnotetext{
${ }^{30}$ John 10:27-30 serves as one of many examples of individual operation, the reiteration of which serves the unity in being and in operation between the Father and Christ.

31 In ontological theology the correlation between the nature of God in Trinity has direct bearing upon the Christian who is conscious of the resemblance in nature and in relationality. The incarnate presence and operation of God in the believer establishes them in the purpose of being the extension, albeit imperfect, of the divine perfection.

32 Genesis 1:23.

332 Peter 1:3-11; 2 Corinthians 3:18, 4:4-11.

34 Galatians 3:26-28; Colossians 3:9-10.

35 John 3:35; 5:19-23; 10:37-38.

36 TIB: Jay P Green, The Interlinear Bible (2 ${ }^{\text {nd }}$ ed.). USA: Hendrickson, 1976. p. 531.
} 
without end) with human existence within that frame. ${ }^{37}$ The human story is therefore integral to the divine metanarrative, drawing its significance from it, as Christ affirmed.

The ontological theology metanarrative, rooted in the being and relationship of God: Father, Son and Spirit, establishes Godhead as: origin, (re)source, raison d'être and end goal of Christian existentialism. ${ }^{38}$ It is manifest by an encounter with the Person of Jesus Christ in an existential way. This paradigm shift is expressed through 'personification'; benefits formerly sought and obtained through religious observance are now an integral part of His Person. He is covenant, is salvation and is glory, (likewise, temple, redemption, justice, life, etc.).

Ontological existentialism's uniqueness is founded upon this unity in Christ, whereby a person is brought into the space and time of Trinitarian existence and life. In this, whereby God restores the existential over the religious and institutional, the relational over the ritual and functional, transformed human nature over external rule and compliance. It is an ontological existence that roots identity, belonging and destiny in Christ. ${ }^{39}$

This view recognizes a metanarrative formed in God's eternity; rather than recreate another, we are invited into His own. In this light, to effect change in a perennial way, is to transform the persons involved. Crisis is a divine interpellation to reconsider this eternal paradigm.

\section{God's Metanarrative: Transcendence and Immanence}

God restoring all things to his original intentions in Christ, ${ }^{40}$ encapsulates the divine metanarrative. According to the biblical texts, the sphere of action is cosmological and terrestrial, accomplished in the person of Christ, a poignant marker of a transcendent reality made immanent. By extension, the ontological Christian's reality is also the meeting of the transcendent and the immanent in Christ, in their being. Eternity in the ontological Christian is a conscious participation in a greater divine history and a demonstration of truths and values that transcend time, generation and era. ${ }^{41}$ It reflects the divine intention that every human being might know the eternal principles that are in God and so manifest them.

This being so, God consciously gives a person or a community to the world, to contribute the thought from eternity in the heart in purposeful collaboration towards, the restoration of all things to his original intentions. In this, $\mathrm{He}$ is resolutely working in the world and in humanity towards this completing fulness ('perfecting') of humanity, the heavens and the earth. ${ }^{42}$ The climactic fulfilment is described as the regeneration ${ }^{43}$ of all creation, the renewing of a quality of existence and life described as "a new heaven and a new earth." ${ }_{4}$ It reflects the perfecting of what has been in process through the ontological Christian within the divine metanarrative.

McKechnie (2001: 102) makes an observation of the early church era,

$\ldots$ at first Christians gave little thought to their own history. The Lord would return soon, ... and put an end to all history. When men give up their jobs, gaze into the heavens, and look for the end of the world, they write no history.

\footnotetext{
37 'owlam is duration of time, antiquity and futurity, continuous, perpetual existence.

The word is paralleled with "He has made everything beautiful in its time" verse 11a. 'eth meaning an event, a measure of time, experiences, opportunities from the root 'ad synonymous with 'owlam.

${ }^{38}$ Colossians 1:16.

39 Galatians 3:26-27; 6:15; Colossians 3:9-10.

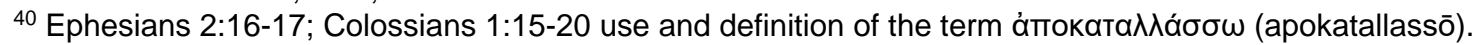

41 Corinthians 1:7.

42 Matthew 24:3; 28:20.

43 Matthew 19:28.

44 Isaiah 65:17; 66:22; 2 Peter 3:1; Revelation 21:1. The Hebrew Old Testament term chadach refers to the repairing or renewing - fresh; synonymously in the Greek New Testament the term kaıvós (kainos) likewise refers to a fresh quality.
} 
This expectation results from a posture of 'immediacy' (now) rather than 'imminence' (soon coming) regarding the return of Christ to reign on earth. Awaiting a sovereign act of God to reestablish the divine order in a heightened state of human chaos and impotence, "the final denouement was conceived realistically as a series of events to be carried out by God on the plane of history" (Kelly, 1968: 472-473, 475). Christian orthodoxy would affirm Christ's future earthly reign of justice and peace ${ }^{45}$ (Bettenson, 1963: 26). However, the early Christian community witness also expressed that "... wherever religion was alive and healthy, the primitive conviction of enjoying already the benefits of the age to come was kept vividly before the believer's consciousness" (Kelly, 1968: 474). With the fading of this reality, "... a weakened consciousness of God's present redemptive action undeniably appeared, along with the implied alteration in the eschatological perspective" (Kelly, 1968: 473).

The ontological metanarrative firmly holds the future hope and the restored significance present in tension and in order. The ontological implications for the Christian with eternity in their humanity provide cohesive meaning to the present and hope to the future in the miracle of collaborating in the divine metanarrative.

These responses should mould the Christian contribution to crises engendered by the global situation and, in response to the belief crisis questions, provide structure to the mindset and formulation of a renewed metanarrative.

\section{Response III: Crisis Interpretation}

From a plethora of crisis interpretations, emerge the broad categorizations of apocalypticism, ${ }^{46}$ conspiracism ${ }^{47}$ and rational-anxiety minimalism ${ }^{48}$ that share the common thread of inducing and nurturing fear that engenders confusion. Resulting loss of anchor points which enable interpretation of events is symptomatic, this fear replaces the faith that induces certain hope and present engagement. This response seeks to demonstrate how the ontological metanarrative provides a defining framework of interpretation and anchorage in the divine purpose.

\section{Apocalypticism}

Apocalyptic refers to cataclysmic destruction whereas eschatological identifies the factors culminating in a climatic finality to world history. "... Apocalyptic literature and eschatology tend to come into their own in periods of crisis"49 (Ferguson and Wright, 1988: 34). According to Ladd (1993: 65), "Contemporary (Judaic) apocalyptic conceived of the (present) age as under the power of evil while God had retreated from the scene of human history..." To interpret signs of a final apocalyptic cataclysm in the human story requires a series of events unprecedential in character, unprecedential and global in reach with heightened intensity or frequency that escape human means. While some may find this analogy through Covid-19, the historical view suggests that is not accurate; at least at the present time. The introductory remarks in the first section of this article substantiate this historically.

History witnesses to generational disruptive crises of the human construct. In the New Testament acknowledges their multiplication and intensification. ${ }^{47}$ Some might see God's sovereign hand as the cause, others could see the crises as the impotency and brokenness of

\footnotetext{
45 The Nicaean Creed, Council of Chalcedon (451).

46 Oxford, "Apocalyptic": describing or prophesying the complete destruction of the world ... momentous or catastrophic. Retrieved $17^{\text {th }}$ February 2021. https://www.lexico.com/definition/apocalyptic

47 Oxford, "Conspiracism": The belief that major historical and political events are brought about as the result of a conspiracy between interested parties, or are manipulated by or on behalf of an unknown group of influential people. Retrieved $17^{\text {th }}$ February 2021. https://www.lexico.com/definition/conspiracism

${ }^{48}$ Rational anxiety minimalism refers to the psychological defence coping mechanism of trying to achieve control of circumstances by reason alone. Anxiety is often the origin of that reaction but also characterizes the out of control-uncontrollable reaction. In both cases minimizing in order to cope can occur.

${ }^{49}$ R. J. Bauckham, "Apocalyptic" New Dictionary of Theology. IVP 1988. P34.
} 
the human construct, and others the works of evil or the Evil One; some will interpret as destruction while others will see reformation of the world system. In times of human crisis, it is “... to find in biblical apocalyptic an assurance of God's purpose at work in history ... and the hope for the climactic achievement of God's purposes in the future when Jesus Christ will come..." (Ferguson and Wright, 1988: 35).

This article contextualizes the redemptive groanings of the planet and humanity in the divine metanarrative. ${ }^{50}$ Disruptive events ${ }^{51}$ for the ontological Christian are held within that

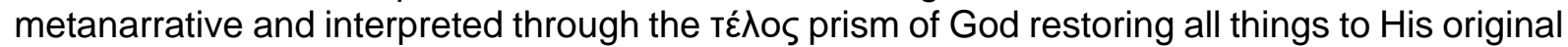
intentions.

The ontological Christian, because of relationship to Godhead, is described as 'eschatological'. What God intends in the final renewing of all things, ${ }^{52}$ is experienced in the present, ontologically and in increasing measure. Disruption, deconstruction, reform and restoration are normative experiences that will intensify and multiply in anticipation of the culmination of the divine intention. Jesus spoke into this present-future, disruptive-restorative tension,

\begin{abstract}
When the Pharisees asked when the apocalyptic Kingdom was coming, Jesus answered ... the Kingdom was already in their midst, ... in some real sense God's Kingdom came into history in the person and mission of Jesus ... (whereby) both present and future are the scene of ... God ... acting and manifesting dynamically his redemptive will in history. (Ladd, 1993: 65, 67, 80, 82)
\end{abstract}

The term 'apocalypse' means "revelation, disclosure or unveiling,"53 in particular of the Person of Christ who is the central focus point for the destiny of the cosmos and for human history. ${ }^{54}$ As Barrett (1987: 328) also perceives, "...one essential notion of apocalyptic is not ... the conviction that the end is near, but that God wills to reveal himself to chosen men ... to communicate the revelation to his people."

The revelatory is restorationist. There exist two tensions in a historical interpretation of God in time. Firstly, the deconstruction of non-conformity to the metanarrative held in polarity with the redemptive construction; secondly, by causing humanity to face cause and effect judgments, both present and future, ${ }^{55}$ in tension with God being restorative and salvific. ${ }^{56}$ This a present and future eschatological principle. Crisis should be interpreted in this light of such purpose.

This view integrates the biblical language of the term tédos meaning fulfilment, completion, perfecting, reflected in the understanding possessed by the biblical writers, ${ }^{57}$ and in the ontological theology metanarrative. The ontological view does not replace the eschatology, it embodies it, nor does an ontological view deny the disruptive crises in the human construct, it articulates the distinction between agency and form by anchorage and interpretation in the overarching metanarrative.

\footnotetext{
50 Romans 8:18-25.

${ }^{51}$ Nations rising against nations, rumours of war, natural disasters, hostility, prevalence of evil (Matthew 24:7, 9, 14; Mark 13:8; Luke 21:24-25).

52 Matthew 19:2.

53 Thayer, J.H. "ámока $\lambda u ́ \pi т \omega "$ Greek-English Lexicon of the New Testament. Hendrickson Publishers 1999.

541 Peter 1:7, 11-13; 4:13; 1 Corinthians 1:7; 2 Thessalonians 1:7.

The term is also used in the present and future contexts of: God (1Co.2:10), Christ (Gal.1:16), the Church (Ep.3:3-5), righteous judgment, Ro.1:17) believers, (Ro.8:18-21), law-less one (2Th.2:3, 8).

55 The underpinning concept of biblical judgment rests upon two criteria: A person is confronted by their own words, intentions and actions and judged by their own measure (Matthew 7:2; Romans 2:1-2; 2 Thessalonians $1: 6)$; and by Jesus spoken word to humankind (John.12:48).

56 Isaiah 30:18-22. The apocalyptic judgment-condemnation discourse must imperatively find the sovereign divine penultimate purpose, the constructionist, restorative, salvific metanarrative. The figurative language of 'birth pains' clearly points to suffering that leads to something new, (Matthew 24:8).

57 Matthew 24:13-14; Acts 2:17; 1 Corinthians 1:8; 15:45; Hebrews 3:6, 6:11; 1 Peter 1:5, 9; 4:7; Revelation 2:26.
} 


\section{Conspiracism}

Conspiracist views according to Reid (no date), "increase in prevalence in periods of widespread anxiety, uncertainty, or hardship, ... and in the aftermath of natural disasters like tsunamis, earthquakes, and pandemics." They are identified by deep suspicion and distrust of the accepted narratives, caused by perceived threat, alienation, and polarized conflictual attitudes. Reid (no date) quotes the Australian philosopher Steve Clarke who proposes "the fundamental attribution error" principle whereby personal traits and motivations outweigh situational factors. Tight knit conspiracist communities are said to manifest heightened critical habits of seeking out the suspicion of error in a person while missing the criteria and norms of context and meaning.

The conspiracist bias often lacks the metanarrative to root and contextualize the assertions, which inevitably align with apocalypticism. The Christian attitude is, in the words of Jesus, "... do not be seduced by the 'pseudo-teachers' ... do not be alarmed or surprised ... do not be scandalized ..." 58 The ontological Christian emphasis is therefore on an informed awareness but positive constructionism that builds with a perspective of eternal values and practices in view of perfect fulfilment.

\section{Rational anxiety minimalism}

The Covid-19 pandemic demonstrates the 'out of control' scenario to which rational minimalizing only underscores the fear that paralyzes; as optimists see in human resource the solution, but fail to explain the why and how, answers can only come from a perspicacious metanarrative. The finality often reflects an underlying atmosphere of unresolved fear of the 'out of control' undermining resolve and resilience.

A common trait in times of crisis results in hankering after a sentimentalized or romanticized view of the past, which early Christians were also prone to,

Controversy to the fore, is a corrective against the view of the apostolic age that would differentiate it from everything which followed. From the second century, Christians began to think there had been something special and irreplaceable about the time when people who had been alive in Jesus' lifetime were still around. They wanted to look back to a better time. (McKechnie, 2001: 93)

This is a reminder of the existential crisis of 'rootlessness' 59 when tribulation shakes the foundations of a person's existence or when a false sense of self-sufficiency fails. These traits are found in apocalypticism extracted from the ontological divine metanarrative, and the obscurantist spirit of conspiracist groups faced with crisis; likewise, the rational-anxiety spirit bound to retrospection appears unable to engage with the unknown of post-crisis change and alterity.

The ontological theological perspective responds to the need of metanarrative anchorage and historic opportunity. This perspective invites ontological Christians to a hope-filled assurance, proactive in the world and in crises as problem solvers according to this construct, "... taking hold of a kingdom (in the present) that cannot be shaken ..."60

\section{Divine Strategy}

In the light of the urgency and immensity of the global task, divine strategy is conceptually infectious and contagious: Covid-19 methodology turned on its head! It begins with individuals

\footnotetext{
58 Matthew 24:4, 6; John 16:1; Luke 21:9 (TIB).

59 Matthew 13:20-21; John 15:5-6.

60 Hebrews 12:25-28.
} 
and communities as carriers and propagators of the vision, values, and practices of this construct: a people movement from the bottom up, effecting change in a time of paradigm instability. ${ }^{61}$

This perspective reflects the confounding exponential growth effect of first century Christians who, in the midst of extreme difficulty and opposition, were driven by the resilience of this ontological existence; 62 a people movement growing and influential that would infect the Roman empire in every strata and region in the space of one hundred and fifty years. In the words of Tertullian, (around $200 \mathrm{CE}$ ), "....we have filled every place among you-cities, islands, fortresses, towns, market-places, the very camp, tribes, companies, palace, senate, forum,we have left nothing to you but the temples of your gods" (Tertullian Apologeticum XXXVII quoted in Schaff, P. 1885: 85).

Christians changed the religion of the Roman world; it was a strange anomaly which made the emperor's personal service possibly the safest place for a Christian to be ... The emperor's servants were the people who really ran the empire. The long-term effects of Christian influence in this context were considerable ... Not only the people who staffed the Palatine Hill (empire-wide public administration) in Rome, but the whole household of Caesar ... all the places owned personally by the emperor (personal administration) ... (McKechnie, 2001: 137138).

\section{Conclusion}

The pandemic overview describes the dynamics of globalisation, emphasizing the historical and repetitive nature of pandemics and the necessary responses to them. Moreover, the pandemic is the means to stress test the systems of globalisation and the genericity upon which it relies to operate, to respond to human decohesion and distrust, and to the socioeconomic depression. Voices have spoken of a need for profound change in recognition of the extent of breakdown in the globalised model.

The ontological theology response seeks to construct divine and eternal relevancy in the understanding of global paradigms and narrative challenges of this era in crisis. The innate limits of the natural order reemphasize the imperative transition from quantitative to qualitative and sustainable. Based on the premise of God as archetype, a metanarrative is established upon the ontology of Godhead in homogeneity and alterity demonstrating a divine model for advocating authentication and validation of uniquity and alterity as a critical address to globalisation. Likewise, the divine metanarrative roots origin, destiny, time and space, in the eternity and culture of Godhead from where a restorative, perfecting constructionism is made immanent in Christ. The eternal principles and values define the present-future vision whereby, the ontological Christian collaborates within the divine metanarrative. Having defined the nature of apocalypticism, conspiracism, rational-anxiety tendencies, the ontological metanarrative provides an interpretive framework and context to escalating crisis disruption, and affirms the uniquity of the incarnate nature of Godhead and the eternal but present perspective of the ontological Christian in human history.

One word reiterated throughout the research for this article is 'resilience': the ability to recover, overcome easily and quickly from difficulty; tenacity or toughness; the capacity to regain original shape ... after ... stretching out of shape; keep your balance, have elasticity ${ }^{63}$ While

\footnotetext{
61 Matthew 13:31-32, 33.

62 The ontological view describes the present reality and forward impetus, and encompasses the eschatological expresses the present existence of ontological believers and the certain hope of the ultimate outcome, the perfection embodied in Christ's personal return and reign.

${ }^{63}$ Collins English Dictionary Home Edition "Resilience" HarperCollins Publishers. 2009. p642.

Dictionnaires Le Robert « Résilience » Le Robert Illustré 2018. SEJER 2018. p1659.
} 
the generational and historical understanding contextualizes the pandemic trajectory, it also shakes the ability of human resilience and belief to confront, traverse, and reemerge. Resilience does not leave place for a sentiment of victimisation; it could also be misconstrued as maintenance of the 'old normal', whereby there is no signficant desire for change, which is to miss the purpose of the historical and divine witness.

In conclusion, a final provoking thought is found in the sobering witness of Dionysius a third century teacher, of which the spirit at least is to be retained,

In many cities of the Roman Empire there was a small body of believers, often ... despised as 'atheists' ... or 'Galileans'. How will they respond in this time of horror and distress? ... Most ... Christian brothers and sisters showed unbounded love and loyalty, never sparing themselves ... following the example of Christ, [caring] for their ... neighbours in their houses, washing wounds, cleaning up the blood and diarrhoea, providing water, food and basic medicines ... exposing themselves to extreme risk. The ancient world had never seen anything like this ... (Wyatt, 2020), and Costantinos, 2020: 568). ${ }^{64}$

\section{References}

Barrett, C. K. (1987). The New Testament Background: Selected Documents. Rev. ed. London: SPCK. p. 328.

Bettenson, H. S. (ed.) (1963). Documents of the Christian Church. Second edition. Oxford: Oxford University Press. p. 26.

Bennett, M. (2020). Trusting the Experts Takes More Than Belief. Centre for Research in the Arts, Social Sciences and Humanities. 11 August 2020. Available at:

www.crassh.cam.ac.uk/blog/post/trusting-the-experts-takes-more-than-belief. (Retrieved 18 December 2020).

Costantinos Berhutesfa Costantinos. (2020). A Pandemic That Is Shifting Human Narratives. Respublica Litereria, Vol XV (No 637) MMXX. Available at:

www.academia.edu/42767617/A_Pandemic_that_is_Shifting_Human_Narratives_RL_Vol_X V_No_637_MMXX. (Retrieved $2 \overline{5}$ November 2020).

Brown, F., Driver, S. \& Briggs, C. (1987). The Brown-Driver-Briggs Hebrew and English Lexicon. With an Appendix Containing the Biblical Aramaic. Online Bible Edition, Larry Pierce. pp. 05769, 05703, 06256.

CBC News. (2008). Cholera's Seven Pandemics. CBC News. Posted 9 May 2008. Last Modified 22 October 2010. Available at: https://www.cbc.ca/news/technology/cholera-sseven-pandemics-1.758504 (Retrieved 18th January 2021).

Collins, Harper. (2009). Collins English Dictionary Home Edition. Glasgow: Harper Collins Publishers. p. 642.

Crossway Bibles. (2007). The Holy Bible: English Standard Version. Wheaton IL: Good News Publishers.

\footnotetext{
${ }^{64}$ Wyatt, John. Emeritus Professor of Neonatal Paediatrics at UCL and Senior Researcher at the Faraday Institute for Science and Religion, University of Cambridge.
} 
Devermont, J. (2020). South Africa's Bold Response to the Covid-19 Pandemic. Center for Strategic and International Studies. 12 May 2020. Available at: www.csis.org/analysis/southafricas-bold-response-covid-19-pandemic. (Retrieved 17 November 2020).

Earth Sky. (2011). What Makes a Tree Stop Growing? 1 January 2011. Earth sky. Available at:earthsky.org/earth/what-makes-a-tree-stop-growing. (Retrieved 1 March 2021).

Ferguson, S. B. \& Wright, D. F. (ed) (1988). New Dictionary of Theology: Apocalyptic. Leicester: IVP Academic. pp. 34-35.

Green, J. P. (1976). The Interlinear Bible (2 ${ }^{\text {nd }}$ ed.). USA: Hendrickson. p. 531.

Henderson, E. S. (2019). A Biblical Examination of an Ontological Reading of Theology in Trinity, in the Believer and in Church (PhD Dissertation, Atlantic Coast Theological Seminary, FL, USA. 2019). doi:10.17913/g8j-ds77. P56-57, 104.

Kelly, J.N.D. (1968). Early Christian Doctrines. Fourth Edition. London: Adam \& Charles Black Ltd, 103911481-J-N-D-Kelly-Early-Christian-Doctrines.pdf. pp. 472-475.

Kharas, H. \& McArthur, J. (2020) Sustainable Development Goals: How Can They Be a Handrail for Recovery. The Brookings Institution. 17 November 2020. Available at: www.brookings.edu/research/sustainable-development-goals-how-can-they-be-a-handrailfor-recovery/ (Retrieved 20 November 2020).

Ladd, G.E. (1993) A Theology of the New Testament. Rev. Ed. Grand Rapids: Eerdmans. pp. $65,67,80,82$.

Lebakeng, T. (2020) Indigenization of Epistemology for African Education. (paper presented at University of Zululand Conference Covid-19: Challenges, Controversy, Commitment and Community Response, 15 December 2020) (Retrieved 15 December 2020).

Robert, Le. (2018). Le Robert Illustré 2018. Dictionnaires Le Robert - Paris: SEJER 2018. p. 1659.

McKechnie, P. (2001). The First Christian Centuries: Perspectives on the Early Church. Leicester: Apollos-IVP. pp. 93, 102.

Molinié-Verdier, A. (2020). TRIBUNE : Health Emergency and Public Liberties: France, Dunce of Europe? ${ }^{65}$ Le Nouvel Observateur. 5 November 2020. Available at:

https://www.nouvelobs.com/politique/20201105.OBS35703/tribune-urgence-sanitaire-etlibertes-publiques-la-france-cancre-de-l-europe.html. (Retrieved 13 January 2021).

Masoga, M. A. (2020). Studies on Indigenous Knowledge Systems. African Century Editions (ACE) Press. pp. 16, 43.

Oliver, G. (2020). Six Ways Covid-19 is changing South Africa. The New Humanitarian. $28^{\text {th }}$ May 2020. Available at: www.thenewhumanitarian.org/feature/2020/05/28/South-Africacoronavirus-positive-changes. (Retrieved 17 November 2020).

Our World in Data. (2020). World Population Since 10000 BCE. Time: 1600-2019. Our World in Data. Available at: ourworldindata.org/grapher/world-population-since-10000-bceourworldindata-series?time=1600.2019. (Retrieved 21 December 2020).

Ozili, P. K. (2020). Covid-19 in Africa Socio-Economic Impact Policy Response and Opportunities. International Journal of Sociology and Social Policy. Available at: www.academia.edu/43021054/COVID_19_in_Africa_socio_economic_impact_policy_respon se_and_opportunities. (Retrieved 17 November 2020).

\footnotetext{
65 Translated from French: « Urgence sanitaire et libertés publiques : La France, Cancre de l'Europe ? »
} 
Reid, S. A. (n.d.). Conspiracy theory. Encyclopedia Britannica, https://www.britannica.com/topic/conspiracy-theory. (Retrieved 4 February 2021).

Rodriguez, Leah (2019) 4 Factors Driving the Water and Sanitation Crisis in Africa. Global Citizen, Johannesburg, 7 October 2019. Available at: globalcitizen.org/en/content/water-andsanitation-crisis-sub-saharan-africa/ (Retrieved 13 March 2021).

Sekyere, E., Bohler-Muller, N., Hongoro, C. \& Makoa, M. (2020). The Impact of COVID-19 in South Africa. The Wilson Center. www.wilsoncenter.org/publication/impact-covid-19-southafrica. (Retrieved 16 November 2020).

Smil, V. (2020) A Complete History of Pandemics. The Mit Press Reader. 30 March 2020. thereader.mitpress.mit.edu/a-complete-history-of-pandemics/ (Retrieved 19 November 2020).

Tertullian. (160-230 ca.) Apologeticum XXXVII. In P. Schaff and A. Menzies (Eds. 1885) Vol.3; Ante-Nicene Fathers, Latin Christianity: Its Founder, Tertullian. Grand Rapids, MI. anf03.pdf. p. 85.

United Nations. (2015) UNICEF urges swift action, 'robust financing' to close water and sanitation gaps in sub-Saharan Africa. United Nations Sustainable Development Goals, 16 December 2015. Available at: un.org/sustainabledevelopment/blog/2015/12/unicef-urgesswift-action-robust-financing-to-close-water-and-sanitation-gaps-in-sub-saharan-africa/ (Retrieved 13 March 2021).

United Nations. (2020) Time to Revise the Sustainable Development Goals. Nature.com. www.nature.com/articles/d41586-020-02002-3. (Retrieved 21 November 2020).

United Nations. (2020) Shared Responsibility, Global Solidarity: Responding to the SocioEconomic Impacts of COVID-19. United Nations Sustainable Development Group. 1 March 2020. unsdg.un.org/sites/default/files/2020-03/SG-Report-Socio-Economic-Impact-ofCovid19.pdf. (Retrieved 24 November 2020).

Waldman, R. \& Claeson, M.. (n.d.). Cholera, Encyclopaedia Britannica. 9 August 2019. https://www.britannica.com/science/cholera/Cholera-through-history\#ref253250 (Retrieved 18 January 2021).

Westcott, B.F, \& Hott, F.J.A. (1881). The New Testament in the Original Greek. Online Bible Edition. Larry Pierce (ed.) New York: Harper \& Brothers.

Worldometers. (2020). World Population and Corona Virus. Worldometers. https://www.worldometers.info/world-population/, https://www.worldometers.info/coronavirus/ (Retrieved 14 December 2020).

Wyatt, J. (2020). Christianity in a Time of Plague. Christian Medical Fellowship. 20 March 2020. https://www.cmfblog.org.uk/2020/03/20/christianity-in-a-time-of-plague/ (Retrieved 11 January 2021). 